\title{
Kriminalisasi Terorisme di Indonesia dalam Era Globalisasi
}

\author{
Muh. Arif Setiawan
}

\begin{abstract}
Criminalisation of terrorism in Indonesia is certainly related to the global dinamization process occurred recently. Viewed substantially the crime of terrorism for specifically international terrorism actually is not the single crime because it can be a transnational crime. Even though through seeing the terrorism of crime correlated to the crimes, the process of criminalization from the various of aspects must be determined comprehensively.
\end{abstract}

\section{Pendahuluan}

Semenjak terjadinya serangan yang diduga dilakukan oleh teroris päda tanggal .11 September 2001 di New York dan Washington Amerika Serikat (AS), terorisme kemudian menjadi perhatian dan masalah serius di seluruh dunia. Betapa tidak, dengan cara membajak pesawat terbang komersial American Airline dan United Airline, teroris menjadikan pesawat tersebut menjadi senjata bunuh diri sekaligus untuk menghancurkan dua simbul keperkasaan Amerika Serikat yaitu menara kembar World Trade Centre di New York sebagai simbul kekuatan perekonomian dan sebagian bangunan pusat Departemen
Pertahanan Amerika yang paling bergengsi "Pentagon" di Washington sebagai simbul kedigdayaan militernya. ${ }^{1}$ Satu pesawat penumpang lagi yang diduga akan ditabrakkan teroris di Gedung Puth temyata jatuh di daerah kosong. Dalam peristiwa tersebut korban yang tewas lebih dari 6000 orang. Peristiwa tersebut kemudian disebut oleh bangsa Amerika sendiri sebagai suatu "Panggilan Pembangun Tidur." ${ }^{\text {2 }}$

"Panggilan Pembangun Tidur" yang dilakukan oleh para teroris tersebut nampaknya betul-betul membangunkan AS dari tidurnya. Kalau saja para kurcac ${ }^{3}$ yang sedang tidur

'Cara yang dipakai teroris tersebut dikenai dengan istilah mass weapons destruction suicide hijack bomb. Lihat bulletinlitbang.dephan.go.id., volume v No.7 Juli 2001.

${ }^{2}$ Transkrip dan Terjemahan Resmi hasil wawancara dengan Wakil Menteri Pertahanan Amerika Serikat Paul Wolfowitz, 2 Desember 2001, Siaran Pers Kedutaan Besar Amerika Serikat di Jakarta.

${ }^{3}$ Gambaran orang yang bertubuh pendek atau kerdil dalam cerita anak-anak. 
diganggu hingga bangun, maka akibat yang terjadi paling-paling sedikit suara berisik para kurcaciyang terusik tidumya, yang nantinya akan hilang dengan sendirinya. Namun bagaimana halnya jika yang diganggu dari tidur nyenyäknya adalah seorang raksasa (baca: Amerika Serikat)? Tentulah bangunnya raksasa tersebut akan menggegerkan jagad karena ia pasti akan mencari pelaku yang mengusik tidumya untuk membuat perhitungan. ${ }^{4}$

Pada saat Amerika Serikat bangun dari "tidur" yang diakibatkan oleh teror, yang terjadi betul-betul kegemparan di seluruh dunia yang diakibatkan oleh cara Presiden Amerika Serikat George Walker Bush Jr mencari pelaku "pembangun tidur" atau pihak-pihak yang membantu pelaku: Karena yang dipikirkan oleh Bush Jr dalam menghadapi para teroris adalah memisahkan mana lawan mana kawan, lalu muncul semboyannya (doktrin) yang menggetarkan siapapun yáng mendengamya: "either you are with us or against us." Kata 'us' disitu bisa berarti ganda yaitu sebagai 'us' yang berarti kami/kita atau singkatan dari 'United States', sehingga sangat kuat kesan adanya keinginan untuk menempatkan dirinya sebagai puncak piramida dari kumpulan negara-negara di dunia. ${ }^{5}$ Indikasi keinginan AS untuk memimpin dunia dalam pemberantasan terorisme makin nampak dari pernyataan lanjutan Presiden AS bahwa AS akan memimpin dunia melawan terorisme. ${ }^{6}$

Semboyan Presiden Amerika tersebut nampaknya benar-benar berpengaruh pada kebijakan politik di banyak negara di dunia, karena mereka bisa menjadi kikuk dan terpaksa harus bersikap untuk memilih sebagai teman atau lawan dari Amerika Serikat. Menurut Agus Subagyo' Doktrin Bush telah membelah dunia. menjadi dua bagian yang terpisahkan, yakni antara ikut kubu AS memerangi terorisme global atau ikut mendukung terorisme global. Negara-negara di dunia dihadapkan pada pilihan sulit dan mau tidak mau harus memilih di antara keduanya. Suasana ini mirip ketika perang dingin antara kubu kapitalis dan komunis. Saat ini dunia dikondisikan oleh doktrin tersebut pada batas-batas terorisme global: zona anti teroris dan zona teroris atau pendukung teroris.

Tampilan politik luar negeri AS pasca tragedi WTC dan Pentagon memang menunjukkan perubahan sangat mendasar, AS sangat represif, ofensif, dan reaktif terhadap negaranegara yang dianggap membahayakan bagi perdamaian dunia dan mengancam keamanan global. ${ }^{8}$ Sebagai bagian dari warga dunia, Indonesia tentu saja tidak akan terlepas dari pilihan sulit tersebut. Indonesia harus menentukan pilihan yang keduanya tentu tidak

\footnotetext{
${ }^{4}$ Ada ungkapan yang sangat tepat dalam bahasa Jawa untuk memberikan gambaran seperti itu yaitu perumpamaan koyo nangèkké macan turu seperti membangunkan macan yang sedang tidur.

${ }^{5}$ Agus Subagyo, "Satu Tahun Tragedi WTC 11 September 2001", harian Kompas. Lihat juga Hikmahanto Yuwono, "Catatan Singkat RUU Anti Terorisme", makalah seminar sehari Terorisme, Fakultas Hukum Universitas Indonesia, Jakarta, Mei 2002.

B "Dunia Nyatakan Perang Lawan Terorisme", Kompas Cyber Media, Jum'at 14 September 2001, htto:ll wuw.kompas.com.

${ }^{7}$ Agus Subagyo, Ibid.

${ }^{8}$ Agus Subagyo, Ibid.
} 
akan terlepas dari konsekuensi atas putusan yang diambil. Situasi sulit yang dihadapi Indonesia menjadi lebih sulit lagi ketika terjadi ledakan bom di Bali yang diduga dilakukan oleh teroris, yang menewaskan lebih seratus delapan puluh orang yang sebagian besar adalah orang asing kulit putih dan sebagian besar diantaranya adalah warga negara Australia. Berkaitan dengan kejadian bom di Bali tersebut Indonesia semakin dituntut oleh dunia intemasional (khususnya oleh AS dan Australia) untuk lebih serius menghadapi aksi terorisme.

Sebenamya sudah agak lama Indonesia merancang Draft RUU Pemberantasan Terorisme, namun karena draft RUU tersebut telah menimbulkan suasana kontroversial yang kemudian terhambat pembahasannya. Kontroversi berputar di sekitar pèrsoalan apakah Indonesia sudah perlu melakukan . pengaturan mengenai pemberantasan tindak pidana terorisme? Apakah undang-undang pidana yang ada sudah tidak memadai untuk menanggulangi terörisme? Apakah yang disebut sebagai terorisme itu sendiri? Serta sejauhmana urgensi perlindungan HAM bagai tersangka/terdakwa pelaku terorisme dalam perspektif due process of law? Apakah kriminalisasi terorisme dapat menjadi peluang penyàlahgunaan kekuasaan sebagaimana pernah terjadi pada waktu masih adanya produk Undang-Undang Pemberantasan Tindak Pidana Subversi karena lenturnya pengertian subversi itu sendiri, sehingga dapat ditafsirkan sesuka hati oleh penguasa.

Belum selesai membahas persoalan kontroversi RUU tersebut, tiba-tiba saja terjadi peledakan bom di Bali pada tanggal 12 Oktober 2002 yang nampaknya "memaksa" Pemerintah untuk segera mengeluarkan peraturan perundang-undangan untuk mengatasi terorisme. Dalam konteks seperti inilah agaknya Pemerintah kemudian mengeluarkan produk Peraturan Pemerintah Pengganti UndangUndang Republik Indonesia (Perpu) Nomor 1 tahun 2002 tentang Pemberantasan Tindak Pidana Terorisme dan Perpu Nomor 2 tahun 2002 tentang Pemberlakuan Perpu Nomor 1 Tahun 2002 tentang Pemberantasan Tindak PidanaTerorisme Pada Peristiwa Peledakan Bom di Bali Pada Tanggal 12 Oktober 2002.

Tulisan ini hendak mengkaji dan menjawab masalah apakah terorisme telah menjadi isu global dan apakah proses kriminalisasi terorisme di Indonesia dipengaruhi oleh isu global terorisme?

\section{Pengertian Terorisme}

Tidak begitu jelas sejak kapan istilah terorisme telah menjadi perbendaharaan kata yang demikian akrab bagi sebagian besar penduduk di muka bumi ini. Secara agak berlebihan ada yang berpendapat bahwa: "Mungkin tidak salah kalau kita mengatakan bahwa sejarah umat manusia adalah rangkaian yang tidak terputus dari aksi.teror yang terjadi dari bentuk yang satu ke bentuk yang lain, dari tempat yang satu ke tempat yang lain, dan dari orang yang satu ke orang yang lain." Sebenarnya apakah yang disebut dengan terorisme itu? Ada yang mengartikan sebagai suatu kegiatan dengan kekerasan atau ancaman kekerasan baik yang menyangkut

${ }^{9}$ Steven Mere, "Siapa Teror Siapa", makalah Poskup, 2002. 
fisik 'atau non fisikuntuk menimbulkan ketakutan atau korban fisik atau'jiwa. Namüñ pengertian tersebut cenderung bersifat menyederhanakan persoalan sehingga belum bisa memberikan batasan pengertian yang jelas. Memang tidak mudah untuk memberikan batasan pengertian terorisme. Salah satu kesulitan untuk melakukan kajian tentang masalah terorisme sebenamya bermula dari pembèrian pengertian istilah terorisme itu sendiri.

Hikmahanto Yuwono, ahli hukum internasional dari Universitas Indonesia juga mengakui sulitnya membuat batasan tentang terorisme, meskipun secara faktual dapat dirasakan dan dapat dilihat adanya karakteristik tertentu dari terorisme. Karakteristik 'terorisme setidaknya meliputi adanya penyerangan dengan kekerasan yang bersifat indiscriminate (membabi buta, sembarangan,pen.), dilakukan di tempat-tempat sipil atau terhadap orang sipil, dan dilakukan sebagai upaya agar pemerintah tertentu tunduk kepada keinginan pelaku. ${ }^{10}$ Sampai saat ini pengertian terorisme dan kejahatan terorisme masih beragam, bahkan AS sendiri yang paling getol mengkampanyekan gerakan anti terorisme temyata belum mempunyai definisi yang jelas mengenai terorisme definisinya masih beragam dan kadang kala rancu."
Tidak heran jika Martin Indyk,seorang mantan duta besar AS di Israel menyebutkan kerancuan definisi terorisme tersebut dengan mengambil contoh konfilik Israel-Palestina. Bahwa yang dianggap teroris oleh orang Israel adalah pejuang kemerdekaan Palestina, sedang menurut orang Palestina yang disebut teroris adalah orang Israel. Atau dalam kasus bom bunuh diri oleh orang Palestina terhadap sasaran di Israel, pelakunya oleh AS dan Israel disebut sebagai teroris, namun bagi Palestina yang diserang bom bunuh diri tersebutlah yang teroris, AS dan Israellah terorisnya. ${ }^{12}$ Oleh karena itu untuk menghindari kerancuan pengertian tersebut, dalam Konferensi Tingkat Tinggi (KTT) Arab di Beirut 27-28 Maret 2002 menghendaki agar perumusan mengenai terorisme membedakan antara terorisme dengan hak sah dari rakyat untuk melakukan perlawanan terhadap penduduk asing dalam rangka membebaskan tanah air mereka sendiri. ${ }^{13}$

Habibie memberikan batasan pengertian terorisme sebagai berikut: ${ }^{14}$

Terrorism is the systematic use of terror or unpredictable violence against governments, publics, or individuals to atttain a political objective.

\footnotetext{
${ }^{10} \mathrm{Hikmahanto}$ Yuwono, op.cit. Penulis sendiri tidak sepenuhnya setuju dengan karakter minimal terorisme tersebut, khususnya yang berkaiatan dengan objek sasaran yang dikatakannya di tempat sipil atau terhadap orang sipil, karena objeknya bisa apa saja termasuk sasaran militer.

11 "Definisi Teroris di AS-pun Masih Rancu", harian Kedaulatan Rakyat, 9 November 2002.

${ }^{12}$ Ibid.

13 "Deklarasi Beirut dan Isu Terorisme", Kompas Cyber Media, Minggu 31 Maret 2002, http.wuw.kompas.com.

14 Bacharuddin Jusuf Habibie, "Human Rights, Human Responsibility, and Human Security", makalah dalam workshop XIX Intemational Workshop on Global Security and the War on Terrorism, diselenggarakan oleh Centre for Strategic Research and BDLI (German Aerospace Industry Association), Berlin, Republic Federal of Germany, 3-6 Mei 2002.
} 
Indriyanto Senoadji juga mengakui bahwa pengertian terorisme ternyata menimbulkan multi interpretasi diantara segala kepentingan negara, pendapatnya tersebut diperkuat dengan argumentasi pengakuan dari amnesty intemational: "there is no universally accepted definition of the word terrorism in general use or in treaties and law designed to combat it."15 Pada awalnya terorisme dikategorikan sebagai kejahatan melawan negara (crimes against state). Namun pengertian tersebut dikhawatirkan akan menimbulkan multi interpretasi yang mengarah pada kepentingan state dimana penguasa dapat memperluas pengertian terorisme menurut kepentingannya sendiri. ${ }^{16}$ Oleh karena itu dalam perkembangan selanjutnya pengertian terorisme temyata bergeser menuju ke arah pengertian yang lebih demokratis. Terorisme kemudian dirumuskan sebagai kejahatan terhadap kemanusiaan (crimes against humanity) yang sifatnya bisa internasional, regional, dan nasional, lebihlebih bila diarahkan pada jiwa-jiwa orang yang tidak bersalah (public by innocent). Pengertian terorisme seperti itu dapat ditemui dalam European Convention on the Suppression of Terrorism (ECST) tahun 1977..$^{17}$

Ada yang berpendapat bahwa meski sejarah istilah terorisme tersebut tidak begitu pasti kapan diketahui, namun dari segi substansinya sebenarnya aksi-aksi yang biasa dilakukan oleh para teroris sudah setua peradaban umat manusia. Ada juga yang berpendapat sebenamya kegiatan teror sudah berlangsung sejak manusia mengenal konflik yang dimulai sejak jaman Jenghis Khan, Revolusi Perancis hingga yang dikenal saat ini, dan pada umumnya terjadi dalam wilayahwilayah yang sedang dilanda konflik. Sejarahwan Yunani yang hidup pada tahun 430-439 SM yang bernama Xenophon pernah mengupas tentang manfaat dan efektifitas perang urat syaraf untuk menakut-nakuti musuh. $^{18}$

Meskipun istilah teror dan terorisme merupakan dua istilah yang berbeda tetapi sebenarnya berasal dari istilah dalam bahasa Latin yang sama yaitu terror atau terrere yang berarti membuat ketakutan yang sangat mendalam. Namun demikian jika dilihat dari segi metode kekerasan kedua istilah tersebut dibedakan pengertiannya. Tidak semua bentuk teror dapat disebut sebagai terorisme. Terorisme adalah puncak aksi kekerasan (terrorism is the apex of violence), demikian menurut Richard Bagun. ${ }^{19}$

${ }_{15}^{\circ}$ Indriyanto Seno Adji, "Bali, Terorisme, dan Hak Asasi Manusia", harian Kompas, 29 Oktober 2002.

${ }^{16}$ Yang dikahawatirkan adalah seperti pada waktu diberlakukannya Undang-Undang Pemberantasan Kegiatan Subversif (UU No:11/PNPS/1963) yang ternyata dipakai oleh penguasa untuk mengebiri kebebasan mengemukakan pendapat sebagai salah satu ciri demokrasi dan hak asasi manusia. Kalau saja pengertian terorisme sangat multi interpretatif, Indriyanto mengkhawatirkan bahwa ungkapan ketidakpuasan terhadap kebjiakan pemerintah dapat dinterpretasikan sebagai terorisme, lihat Indriyanto Seno Adji. Ibid.

${ }^{17}$ Indriyanto Seno Adji. Ibid., lihat juga Indriyanto, "Terorisme dan Hukum", harian Kompas 24 September 2001.

${ }^{18}$ Harian Kompas, "Terorisme Gejala Global", Kamis 20 September 2001. Juga Ahwil Luthan, "Terorisme", makalah seminar sehar "Sosiologi Hukum" yang diselenggarakan oleh Program Pascasarjana Fakultas Hukum Universitas Pelita Harapan, Jakarta, 25 Maret 2002.

${ }^{19}$ Richard Bagun, "Indoṇesia di Peta Terorisme Global", harian Kompas, 17 Nopember 2002. 
Menurut Loudewijk terorisme dapat didekati dari berbagai macam sudut pandang keilmuan seperti sosiologi, kriminologi, politik, hubungan internasional, dan hukum. Kesulitan untuk merumuskan pengertian terorisme karena pengertian yang dibuat akan sulit untuk mencakup seluruh aspek dan dimensi dari berbagai sudut dan disiplin ilmu tadi. ${ }^{20}$ Lebih lanjut Loudewijk mengajukan tiga macam contoh pengertian terorisme yaitu: 1) Menurut konvensi PBB tahun 1937 terorisme adalah segala bentuk tindak kejahatan yang ditujukan langsung kepada negara dengan maksud menciptakan bentuk teror terhadap orang-orang tertentu atau kelompok orang atau masyarakat luas. 2) Menurut US Department of Defense tahun 1990, terorisme adalah perbuatan melawan hukum atau tindakan yang mengandung ancaman dengan kekerasan atau paksaan terhadap individu atau hak milik untuk memaksa atau mengintimidasi pemerintah atau masyarakat dengan tujuan politik, agama, atau ideologi. 3) Menurut TNI AD, berdasarkan Bujuknik tentang anti teror tahun 2000, terorisme adalah cara berfikir dan bertindak yanig menggunakan teror sebagai teknik untuk mencapai tujuan.
Dalam perspektif hukum positif, masalah terorisme di Indonesia sekarang ini diatur dalam Perpu Nomor 1 tahun 2002 tentang Pemberantasan Tindak Pidana Terorisme. Meskipun istilah terorisme merupakan istilah yang sangat penting, namun ternyata istilah tersebut tidak dijelaskan dalam Ketentuan Umum Perpu, padahal biasanya istilah penting dalam perundang-undangan selalu dijelaskan dalam Ketentuan Umum. Yang dijelaskan dalam Ketentuan Umum (Bab I Pasal 1 angka 1) adalah pengertian tindak pidana terorisme yaitu: "segala perbuatan yang memenuhi unsur-unsur tindak pidana sesuai dengan ketentuan dalam Perpu ini." ${ }^{21}$

Pengertian terorisme ternyata dijelaskan dalam bagian Penjelasan Umum Perpu yaitu: "kejahatan terhadap kemanusiaan dan peradaban serta merupakan salah satu ancaman serius terhadap kedaulatan setiap negara karena terorisme sudah merupakan kejahatan yang bersifat internasional yang menimbulkan bahaya terhadap keamanan, perdamaian dunia serta merugikan kesejahteraan masyarakat..." ${ }^{22}$ Dalam bagian Penjelasan Umum mengenai sifat kekhususan Perpu Nomor 1 dalam angka 4 dijelaskan lebih lanjut

${ }^{20}$ Loudewijk F. Paulus, "Terorisme", bulletin Litbang Departemen Pertahanan RI. http:/l www.buletinlitbang.dephan.go.id.

${ }^{21}$ Pemberian pengertian istilah tersebut sebenarnya tidak memberikan penjelasan karena kita harus mencarinya lagi dalam bagian lain dalam Perpu yang dalam hal ini terdapat dalam Bab III Pasal 6 sampai dengan 19. Justru dalam draft RUU Pemberantasan Terorisme istilah terorisme diberi batasan pengertian yang dimuat dalam Ketentuan Umum Bab I Pasal I angka 1 yaitu: Terorisme adalah tindakan dengan menggunakan kekerasan atau ancaman kekerasan yang berlatarbelakang dan atau bertujuan politik dengan kegiatan dalam bentuk sebagai berikut:

a. Menimbulkan bahaya atau ancaman bahaya bagi nyawa orang lain;

b. Menghancurkan harta benda;

c. Menghilangkan kebebasan pribadi; atau

d. Menciptakan perasaan takut pada masyarakatluas.

22 Penjelasan Umum Perpu Nomor 1 tahun 2002 tentang Pemberantasan Tindak Pidana Terorisme. 
bahwa: ."... tindak pidana terorisme dikecualikan dari tindak pidana politik atau tindak pidana yang bermotif politik atau tindak pidana yang bertujuan politik..."23

\section{Terorisme sebagai isu Global}

Fenomena' serangan yang diduga dilakukan oleh teroris terhadap WTC dan Pentagon yang mempergunakan sarana pesawat terbang komersial sebagai mass weapons destructions suicide hijack bomb untuk menghancurkan objek sasaran nampaknya merupakan suatu teknik atau metode penyerangan yang tidak pernah disadari siapapun. ${ }^{24}$ Para teroris nampaknya telah memperkenalkan teknik baru yang tidak pernah dikenal sebelumnya oleh para teroris klasik. Para teroris yang mempergunakan metode klasik biasanya hanya terbatas untuk melakukan pembajakan, penculikan, penyanderaan, penyitaan, penyiksaan ataupun pembunuhan biasa. Hal ini menunjukkan bagaimana teroris telah mempergunakan teknologi tinggi untuk melakukan aksinya yang dapat dilihat oleh publik sehingga meciptakan "daya kejut" yang berintensitas tinggi untuk menyampaikan suatu pesan tertentu.

Kasus terorisme 11 September di AS tersebut sebenarnya tidak terlepas dari proses globalisasi yang sedang berlangsung sampai saat ini. Para teroris tersebut ternyata mampu mempergunakan perkembangan ilmu dan teknologi untuk mencapai tujuannya. Globalisasi terjadi akibat penemuan dan peningkatan ilmu dan teknologi terutama di bidang informatika, yang demikian pesat. Menurut Prof. IS. Susanto, globalisasi dapat mempengaruhi peningkatan mobilitas orang, modal, kultur, baik yang bersifat lokal, nasional, bahkan internasional. ${ }^{25}$

Istilah globalisasi seringkali disalah artikan seolah olah hanya berkaitan dengan masalah perekonomian yang melibatkan persoalanpersoalan hubungan global. Namun tidak demikian bagi Giddens: ${ }^{26}$

"Globalisasi bukan hanya, atau bahkan terutama, tentang ketergantungan ekonomi, tetapi tentang transformasi waktu dan ruang dalam kehidupan kita. Peristiwa di tempat yang jauh, entah yang berkaitan dengan ekonomi atau tidak, mempengaruhi kita

${ }^{23}$ Pengecualian tindak pidana terorisme dari tindak pidana politik atau tindak pidana bermotif politik dimaksudkan sebagai cara untuk lebih efektif untuk memberantas terorisme dalam kerangka kerjasama bilateral atau mulitilateral. Misalnya untuk keperluan dilakukannya ekstradisi berdasarkan Undang Undang Nomor 1 Tahun 1979 tentang ekstradisi, dalam Pasal 5 ayat (1) ekstradisi tidak dapat dilakukan terhadap kejahatan politik atau yang bermotif politik.

${ }^{24}$ Meskipun dalam film "Tora Tora Tora" yang memuat dokumen mengenai Perang Dunia II di Pearl Harbour terdapat gambaran bagaimana pilot-pilot pesawat tempur Jepang yang melakukan aksi bunuh diri dengan mempergunakan pesawat tempurnya untuk diarahkan masuk ke dalam cerobong kapal perang AS, sehingga pesawat tersebut meledak beserta dengan kapalnya sekaligus.

${ }^{25}$ IS. Susanto. penjelasan lesan, kuliah 2 Oktober 2001, PDIH Undip.

${ }^{26}$ Anthony Giddens. The Third Way: The Renewal of Social Democracy", diterjemahkan oleh Ketut Arya Mahardika, Jalan Ketiga: Pembaharuan Demokrasi Sosial (Jakarta: Gramedia Pustaka Utama, cetakan ketiga, 2000), hlm 35. 
secara lebih langsung dan segera dari pada yang pemah terjadi sebelumnya. Sebaliknya, keputusan yang kita ambil sebagai individuindividu seringkali memiliki implikasi global. Kebiasaan makan masing-masing individu, misalnya, mempengaruhi para produsen makanan yang mungkin hidup di sisi lain dunia ini".

Globalisasi lanjut Giddens ${ }^{27}$ adalah rentangan proses yang kompleks, yang digerakkan oleh berbagai pengaruh politis dan ekonomis. Globalisasi mengubah kehidupan sehari-hari, terutama di negara berkembang, dan pada saat yang sama ia menciptakan sistemsistem dan kekuatan-kekuatan transnasional. yang baru. Dalam konteks suasania pengaruh globalisasi itulah agaknya persoaian terorisme di dunia ini akan berdampak pada kehidupan hukum di Indonesia.

Dalam proses transformasi ruang dan waktu dalam kehidupan kita sebagaimana dikemukakan Giddens untuk menjelaskan pemahaman mengenai globalisasi, 'suka ataupun tidak suka, dikehendaki ataupun tidak, maka apa yang telah menjadi suatu isu global seperti masalah terorisme akan berimplikasi terhadap perkembangan kehidupan hukum di Indonesia. Menurut Tajuk Rencana Harian Kompas, globalisasi tidak lagi menyangkut masalah politik, ekonomi, dan sosial budaya. Globalisasi juga menerpa bahkan melibatkan masalah keamanan, baik keamanan antar bangsa maupun keamanan domestik. ${ }^{28}$

Terorisme dan segala macam manifestasi dari terorisme sangatlah absurd untuk dipahami dan dimengerti, sehingga tidak heran-jika untuk menanggulangi perlu kehati-hatian, menurut Richard Bagun, ${ }^{29}$ kegiatan terorisme tidak sama dengan perang yang jelas siapa kawan siapa lawan, dalam perang sekalipun serangan lawan seringkali dapat dihitung dan diperkirakan sehingga ada persiapan untuk antisipasi ataupun untuk melakukan serangan balik. Namun tidak demikian jika berhadapan dengan aksi teroris, yang dapat melakukan serangan secara tiba-tiba, tertutup dan tersembunyi lalu lari (hit and run, pen.). Terorisme juga tidak sama dengan teror yang dilakukan oleh mafia atau yakusa, karena jika mafia atau yakusa'melakukan aksi teror ia pasti melakukan langkah pengamanan untuk melakukan gerakan aksi tutup mulut bagi seluruh anggotanya (omerta), namun tidak demikian dengan terorisme yang seringkali (meski tidak selalu) bahkan memberitahukan siapa aktor dibalik dilakukannya serangan teror tersebut. Terorisme juga tidak sama dengan vandalisme ataupun intimidasi biasa.

Dilihat dari aspek kesejarahan, aksi terorisme sebenamya potensial dapat terjadi di semua masyarakat dunia dan tidak mengenal asal ras, bangsa, kewarganegaraan, atau bahkan agama. Menurut Hikmahanto ${ }^{30}$ aksi teror sebenamya pernah dilakukan untuk tujuan komersial untuk mendapatkan sejumlah uang, kemudian aksi teror juga pemah dipergunakan untuk tujuan melepaskan orang-orang yang sedang berada dalam penjara karena menjalani hukuman, dan selanjutnya tindakan terorisme lalu dipergunakan untuk tujuan-tujuan politik.

\footnotetext{
${ }^{27}$ Giddens, Ibid., him 38.

28 "Isu Terorisme Jangan Memecah Belah Kita", harian Kompas, Senin 23 September 2002.

${ }^{20}$ Richard Bagun. Ibid.

${ }^{30}$ Hikmahanto Yowono, op.cit.
} 
Sampai abad ke delapan belas, untuk mencapai tujuannya aksi terorisme masih menunjukkan pola-pola klasik seperti melakukan penculikan, pembunuhan, penyanderaan, pembunuhan, penyitaan dan lain sebagainya. Pada awalnya terorisme merupakan suatu kelompok perlawanan untuk menghadapi penguasa (pemerintah) seperti dalam kasus Narodnaya Volya di Rusia pada pertengahan abad ke sembilan belas. Seiring dengan berjalannya waktu, temyata terjadi pergeseran dalam aksi-aksi terorisme, dimana Narodnaya Volya yang semula dibentuk untuk melawan penguasa kemudian justru dipakai oleh penguasa untuk menindas masyarakat. ${ }^{31}$

Revolusi Perancis merupakan suatu gerakan untuk melakukan pembebasan dari penindasan praktek kekuasaan raja yang absolut dengan semboyannya yang sangat terkenal "liberty, equality, fratemity" (kebebasan, kesederajatan, dan persaudaraan), yang diilhami oleh buku Jean Jacques Rousseau yang berjudul The Social Contract. Namun sejarah juga mencatat bahwa revolusi Perancis tersebut juga dilakukan dengan caracara menyebarkan teror terhadap pihak-pihak penentang revolusi. Wilson dalam bukunya yang sangat terkenal ${ }^{32}$ ketika membahas mengenai zaman pencerahan (enlightenment) mengulas ide JJ. Rousseau mengenai the general will (kehendak umum), yang menyatakan bahwa mereka yang tidak menganut general will yang sudah disetujui oleh dewan perwakilan rakyat ini merupakan penentang atau penyimpang.
Tidak ada cara lain untuk mencapai demokrasi yang benar-benar bersifat egalitarian dan untuk itu perlu dilakukan pemutusan humanity dari ikatannya, karena itu menurut Rousseau humanity harus diikat di manapun. Gagasan Rousseau tersebut ternyata telah ditangkap dengan baik oleh Robespiere yang mempunyai julukan "sang pemimpin pemerintahan teror" (leader of the Reign of Terror). la bersama-sama dengan para Jacobin dengan maksud untuk melaksanakan gagasan Rousseau tersebut kemudian menangkap tiga ratus ribu orang dari golongan ningrat, pendeta, pembelot politik, atau pembuat masalah lainnya yang dianggap menentang. Dalam tragedi yang terjadi pada tahun 1793 itu sekitar seribu tujuh ratus orang meninggal dunia.

Menurut pemahaman Robespiere, tujuan para Jacobin tersebut sebenamya mulia, karena mereka melakukan itu untuk mencapai kenikmatan kebebasan dan kesederajatan masyarakat. Kemudian terjadilah penalaran berikutnya bahwa mereka yang tidak berkomitmen dengan kehendak masyarakat lebih baik harus keluar dari masyarakatnya. Untuk mencapai tujuan tersebut kalau perlu harus dilakukan dengan penaklukan. Temyata penalaran seperti inipun dikemudian hari dipergunakan oleh Napoleon Bonaparte dengan para tentaranya. Berkenaan dengan hal ini menurut Wilson ${ }^{33}$ telah terbentuk suatu kebersamaan antara ideologi egalitarian dengan pemaksaan secara biadab, dan bahkan hal itu terus berlangsung sampai dua abad berikutnya.

${ }^{31}$ Terorisme Gejala Global", harian Kompas, Kamis 20 September 2001.

${ }^{32}$ Edward O. Wilson, Consilience: The Unity of Knowledge (New York: Knopf, 1998), him 15-16.

${ }^{33}$ Wilson, Ibid., hlm. 15-16. Di sini disebutkan oleh Wilson bahwa: "Thus fook form the easy cohabitation of egalitarian ideology and savage coercion that was plague the next two centuries". 
Beberapa rezim pemerintahan lainnya tercatat dalam sejarah juga pernah mempergunakan metode pendekatan terorisme untuk menyingkirkan lawan-lawan politiknya atau pihak-pihak yang dianggap membangkang. Misalnya Rezim Hitler di Jerman, Rezim Pol Pot di Kamboja, Stalin di Uni Soviet, Musolini di Italia dan lain sebagainya. Perkembangan negara dan sistem pemerintahan dituntut untuk semakin demokratis sehingga "memaksa" mereka untuk tidak melakukan teror terhadap lawan politiknya atau kalaupun "terpaksa" melakukan, mereka akan melakukannya dengan caracara yang samar, atau tertutup. Namun dilain pihak yang terjadi dalam kelompok-kelompok teroris justru semakin berkembang dan bermunculan dimana-mana dan bahkan tidak jarang yang mempunyai jaringan internasional dan mereka juga melakukan kerjasama dengan kelompok teroris lain di luar basis negaranya. ${ }^{34}$

Perkembangan kelompok teroris sebenarnya dapat dilihat dari perbedaan-atau persamaan dari aspek tujuan, motivasi, ataupun ideologinya ${ }^{35}$ bandingkan dengan yang dibuat oleh Loudewijk F Paulus yang untuk memahami terorisme secara lebih mendetail. la melihat dari aspek ciri-ciri, karakteristik, motif, sifat intemasional, tujuan, cara kerjajaringannya, cara operasinya (termasuk metode dan taktiknya) ${ }^{36}$ Menurut Ahwil Luthan, perkembangan kelompok teroris di dunia sampai saat ini diperkirakan lebih dari 50 kelompok yang tersebar dimana-mana dengan berbagai macam perbedaan atau persamaan tujuan, motivasi, dan ideologinya. Beberapa nama organisasi teroris yang terkenal::37 1) di kawasan Timur Jauh: Sekigun (Tentara Merah Jepang); 2) di Timur Tengah: Black September yang terkenal dengan kasus penyanderaan atlet olimpiade Munich dari israel (1972), Lohame Herut di Israel, Irgun Zvai Leumi, dan As Sa'ga; 3) Di Eropa: BaaderMeinhof, Rotee Armee Fraktion di Jerman. Di Italia ada Brigate Rosse / Red Brigade (Brigade Merah), di Irlandia Utara ada IRA (Irish Republican Army), dan di Basque Spanyol ada ETA (Euskadi ta As-katasuna) atau juga Basque Nationalist Movement, di Nederlan terdapat Red Help Group, di Perancis ada France's Direct Action, di Belgia ada Belgium's Fighting Communist Cell. 4) Di Amerika Latin: FARC (Fuerzas Armadas Revolucionarias de Colombia). di Kolombia, CAL (Comandos Armados de Liberacion) di Puerto Rico,

${ }^{34}$ Harian Kompas Cyber Media, 20 September 2001. "Indonesia di Peta Terorisme Global", harian Kompas, 17 Nopember 2002. Lihat juga Ahwil Luthan, op.cit.

${ }^{35}$ Ahwil Luthan, op.cit.

${ }^{36}$ Loudewijk F. Paulus, "Terorisme", Buletin Litbang Departemen Pertahanan, didowndload dari http:ll buletinlitbang.dephan.go.id.

${ }^{37}$ Data diperoleh antara lain dari Kompas; 20 September 2002 baik yang dari edisi online maupun cetak, dan dari Ahwil Luthan. Bandingkan perkembangannya dengan daftar nama teroris tambahan versi pemerintah AS yang diumumkan Departemen Keuangan melalui Kedutaan Besar AS di Jakarta pada tanggal 17 Oktober 2001 terdapat tambahan 39 nama teroris yang kesemuanya dengan nama yang "berbau" Timur Tengah dan Islam. http://usembassy.state.gov/Jakarta/www.htrrs.htm1. Daftar tersebutbelum termasuk tambahan baru yang telah dimasukkan dalam daftar di PBB seperti kelompok Jamiah Islamiyah karena kelompok ini dianggap sebagai bagian darijaringan Al-Qaeda di Asia. 
Sendero Luminoso (Jalan Terang) di Peru. 5) Di Kanada: FL.Q (Front de Liberacion du Quebec).

Beberapa kelompok teroris, termasuk yang telah disebutkan diatas dapat dikelompokkan dalam beberapa ideologi, motivasi dan tujuan yang melatarbelakangi dilakukannya aksi teroris. Mantan Presiden RI Habibie ${ }^{38}$ mencoba mengkategorikannya ke dalam empat macam kategori dimana, setiap kelompok bisa saja hanya memenuhi satu macam namun bisa juga lebih dari satu macam latar belakang: 1 . In anti-colonial conflicts (. Ireland and the United Kingdom, Algeria and France, Vietnam and France/United States); 2. In disputes between different national groups over possession of contested homeland (Palestinians and (srae $)_{;}^{39} 3$. In conflicts between different religious denominations (Catholics and Protestants in Northern Ireland); 4. In intemal conficts between revolutionary forces and established governments (Malaysia, Indonesia, the Philippines, Iran, Nicaragua, El Salvador, Argentina).

Dari seluruh kelompok teroris yang disebutkan di atas dan yang terdapat dalam daftar yảng dikeluarkan US Embassy di Jakarta, dan daftar yang ada di PBB, temyata tidak ada satupun jaringan teroris yang berasal dari Indonesia. Namun demikian apakah kemudian Indonesia tidak ada kelompok teroris? !ni merupakan pertanyaan yang cukup sulit untuk dijawab jika tidak ada bukti mengenai hal itu. Tetapi jika dilihat dari rangkaian terjadinya peristiwa percobaan pembunuhan terhadap presiden Soekamo dan rombongannya di Cikini dengan mempergunakan granat tangan (30 November 1957), kasus pembajakan pesawat Garuda (kasus pesawat GIA-Woyla tahun1981), peledakan bom di candi Borobudur (20 Januari 1985), peledakan Masjid Istiqlal (19 April 1999), serangkaian peledakan bom di malam Natal di Bekasi, Jakarta, Tangerang (24 Desember 2000), serta.terakhir 12 Oktober 2002 adalah peledakan bom di Kuta Bali yang menewaskan sekitar seratus delapan puluh orang, kesemuanya itu sebenamya menunjukkan adanya indikasi bahwa di Indonesia telah terjadi aktifitas terorisme meskipun belum diketahui berasal dari kelompok mana.

Fenomena di atas menunjukkan bahwa terorisme benar-benar telah menjadi gejala global. Menurut Richard Bagun, internasionalisasi terorisme tidak hanya berarti bahwa organisasi terorisme yang satu menjadi inspirasi bagi ide atau kegiatan untuk kelompok yang lain namun juga terjadinya hubungan timbal balik dalam bidang latihan, dukungan logistik, personal, dan bahkan orientasi ideologis yang sama. ${ }^{40}$ Apabila terorisme telah menjadi gejala global bukankah berarti bahwa terorisme tidak hanya merupakan masalah suatu negara atau kawasan tertentu saja?

Apabila terorisme telah menjadi gejala global, berarti terorisme juga menjadi masalah global, tidak lagi hanya menjadi masalah nasjonal dari negara yang menjadi korban terorisme. Masalah terorisme harus diatasi bersama-sama oleh masyarakat internasional. Departemen Luar Negeri kita melalui juru

${ }^{38}$ Bacharuddin Jusuf Habibie, op.cit.

${ }^{39}$ Lihat catatan kaki nomor 11 tentang kerancuan itu dengan contoh yang diberikan oleh Martin indyk dalam kasus konflik Palestina dengan Israel, ada ketidak jelasan mana yang teroris, Israel atau Palestina?

${ }^{40}$ Harian Kompas, 20 September 2001, http:/hww.kompas.com 
bicaranya Marti Natälegawa bahwa'menyatakan: "masalah terorisme kini tidak saja menjadi masalah satu kawasan tertentu saja, tetapi menjadi masalah global. ${ }^{41}$ Pemyataan tersebut sejalan dengan paparan Menteri Luar Negeri kita ketika menanggapi secara resmi sikap Indonesia terhadap serangan teroris 11 September 2001 bahwa terorisme menjadi isu global, dan Indonesia mengutuk tindakan terorisme dan mendukung upaya global untuk memerangi terorisme dan mengambil langkah-langkah nasional untuk melaksanakan Resolusi Dewan Keamanan PBB No.1373 tahun 2001.42

\section{Kriminalisasi Terorisme ${ }^{43}$}

Merujuk pada pendapat Giddens bahwa globalissasi pada dasarnya adalah suatu proses transformasi ruang dan waktu dalam kehidupan kita, maka sebenarnya proses transformasi yang terjadi dalam proses globalisasi akan menyentuh semua aspek kehidupan manusia, termasuk dalam bidang hukum. Oleh karena itu dalam setiap proses globalisasi, suatu negara akan menghadapi masalah di bidang hukum terutama yang berkaitan dengan persoalan pergeseran nilainilai dan paradok nilai-nilai akibat masuknya nilai-nilai baru dari luar, serta persoalan bagaimana hukum dituntut untuk merespon terjadinya pergeseran ataupun perubahan nilai-nilai tersebut dalam program legislasi nasionalnya. Setidak-tidaknya mengusahakan pembaharuan hukum melalui pendekatan harmonisasi hukum. ${ }^{44}$ Dalam beberapa hal perkembangan hukum di Indonesia sebenamya juga tidak dapat dilepaskan dari konteks proses

"Laporan Reporter Rio dari forum Southwest Pacific Dialogue (SPWD) yang menyelenggarakan pertemuan di Yogyakarta tanggal 5 Oktober 2002 dengan agenda utama "masalah terorisme di kawasan Pasifik Barat Daya", http://www.skopeonet.com/newsfokus. Sebagai catatan, menurut Marti Natalegawa SWPD diluncurkan pertama kali oleh Indonesia tahun 2000 untuk melengkapi dan memperkuat struktur hubungan indonesia dengan Negara-negara tetangga dekat terutama di kawasan timur. SWPD bukan merupakan organisasi sub kawasan baru melainkan untuk menjembatani peningkatan intensitas hubungan antara Negara-negara di Pasifik Barat Daya dimana disitu ada ASEAN dan ada pula Pacific Island Forum.

${ }^{42}$ Hasan Wirayuda, Paparan Lisan (Executive Summary) Pernyataan Pers Akhir Tahun Menteri Luar Negeri Indonesia, Jakarta, 7 Januari 2002.

${ }^{43}$ Yang dimaksud kriminalisasi adalah suatu proses dijadikannya suatu bentuk perbuatan tertentu yang semula bukan merupakan tindak pidana kemudian dirumuskan menjadi tindak pidana menưruthukum pidana yang beriaku. Kriminalisasi dapat berupa perumusan tindak pidana yang baru sama sekali, atau berupa perluasan pengertian dari tindak pidana yang sudah ada sebelumnya. Mengenai masalah berbagai aspek yang perlu dipertimbangkan dalam proses kriminalisasi, lihat Barda Nawawi Arif, Bunga Rampai Kebijakan Hukum Pidana (Bandung: PT. Citra Aditya Bakti, 1996), hlm 33-34. Diingatkan oleh Barda bahwa penggunaan hukum pidana harus memperhatikan: 1) tujuan pembangunan hukum nasional; 2) Perbuatan yang akan dicegah atau ditanggulangi adalah yang dikehendaki masyarakat (yang mendatangkan kerugian); 3) harus memperhitungkan prinsip biaya dan hasil; 4) harus memperhitungkan kemampuan aparat dan badan penegak hukum.

${ }^{44}$ Pendapat seperti ini pernah dikemukakan oleh Prof. DR. IS. Susanto dalam diskusi kelas PDIH UNDIP tahun 2002 ketika membahas mengenai masalah Globalisasi dan. Hukum. Semarang, 2 Oktober 2001. 
globalisasi terutama yang terjadi dalam proses kriminalisasi terorisme.

Sebagai bagian dari masyarakat dunia, Indonesia akan terkena imbas dari isu global terorisme. Sebagai konsekuensi logisnya Indonesia akan dihadapkan pada masalah untuk membuat keputusan mengenai bagaimana mensikapi atau merespon terorisme global. Apabila AS sebagai negara super power satusatunya di dunia ini telah bersikap bahwa: "kalau Anda bukan teman saya, pastilah Anda adalah musuh saya", maka hal itu akan berimplikasi pada sikap politik kita untuk memilih menjadi kawan atau lawan AS. AS berkeinginan untuk memerangi terorisme dengan caranya sendiri dan mengajak pada semua negara untuk bersatu dengan AS memerangi terorisme, jika ada negara yang tidak setuju maka dapat saja ia dianggap sebagai musuh AS. Siapakah yang berani menentang keinginan $A S$ tersebut? ${ }^{45}$

Dilihat secara substansial, kejahatan terorisme khususnya terorisme internasional, sebenamya bukan merupakan kejahatan yang berdiri sendiri karena ia dapat menjadi kejahatan lintas negara (transnasional), maka terorisme saling berkaitan dengan bentukbentuk kejahatan lainnya seperti penyelundupan senjata, perdagangan gelap obat-obatan terlarang dan narkotika, dan pencucian uang (money laundering) dan lain sebagainya. ${ }^{46}$ Meskipun sebatas yang diketahui penulis, secara formal pengertian tindak pidana terorisme dalam sistem perundang-undangan nasional kita baru diperkenalkan dalam Peraturan Pemerintah Pengganti Undang-Undang (Perpu) Nomor 1 tahun 2002 tentang Pẹmberantasan Tindak Pidana Terorisme dan Perpu Nomor 2 tahun 2002 tentang Pemberlakuan Perpu Nomor 1 tahun 2002 tentang Pemberantasan Tindak Pidana Terorisme Pada Peristiwa Peledakan Bom di Bali Tanggal 12 Oktober 2002.

Namun dengan mengingat keterkaitan kejahatan terorisme dengan bentuk-bentuk kejahatan lainnya maka sebenarnya proses kriminalisasi untuk menanggulangi kejahatan terorisme sudah berlangsung cukup lama, yaitu jauh sebelum dikeluarkannya Perpu tersebut. Beberapa produk undang-undang yang mengatur mengenai tindak pidana yang sebenarnya erat kaitannya dengan masalah pemberantasan tindak pidana terorisme antara lain dalam Undang-Undang Nomor 4 Tahun 1976 tentang Perubahan dan Penambahan Beberapa Pasal Dalam KUHP Bertalian Dengan Perluasan Berlakunya Ketentuan Perundangundangan Pịdana, Kejahatan Penerbangan dan Kejahatan Terhadap Sarana/Prasarana Penerbangan, Undang-Undang Nomor 51/Drt 1951 tentang Larangan menyimpan, memakai, dan memiliki senjata api dan bahan peledak, serta Undang-Undang Nomor 15 Tahun 2002 tentang Tindak Pidana Pencucian Uang.

Menurut Zen, sebagai negara anggota PBB, Indonesia tunduk pada ketentuan Pasal 55 piagam $P B B$ yang intinya setiap anggota $P B B$ wajib untuk mengikatkan diri pada kesadaran untuk menciptakan kondisi keadilan dan

${ }^{45}$ Lihat Hikmahanto Yuwono, op.cit., yang menyarankan untuk mengkritisi kebjjakan luar negeri ASkhususnya yang berkaitan dengan masalah terorisme.

${ }^{48}$ Departemen Luar Negeri AS merupakan salah satu pihak yang berpendapat seperti itu. Lihat Andy Rahmianto, "Indonesia dan Terorisme Internasional", Kompas Cyber Media, 29 Oktober 2001, http:II unw.kompas.com 
perdämaian global. ${ }^{47}$ Pasal 7 Piagam PBB juga mengamanatkan tentang keikutsertaan setiap anggota untuk memelihara atau memulihkan perdamaian dan keamanan nasional..$^{48}$ Oleh karena itu ketentuan-ketentuan hukum pidana Indonesia yang berkaitan dengan terorisme ataupun mengenai terorisme jika ditelusuri sebenarnya mempunyai kaitan dengan situasi intemasional yang sedang berlangsung. Karena situasi internasional dapat berpengaruh terhadap situasi nasional, maka dalam melaksanakan pembangunan hukum di indonesia tidak dapat begitu saja mengabaikan situasi internasional tersebut.

Dikeluarkannya Undang Undang Nomor 4 Tahun 1976 Tentang Kejahatan Penerbangan dan Kejahatan Terhadap Sarana/Prasarana Penerbangan sebenarnya tidak lepas dari diberlakukannya tiga buah konvensi intemasional yang kemudian disahkan dalam Undang-Undang Nomor 2 Tahun 1976. Tiga buah konvensi yang dimaksud adalah: Tokyo Convention/Konvensi Tokyo 1963 yang mengaturtentang kejahatan yang dilakukan di atas pesawat terbang/kejahatan terhadap keamanan penerbangan (Convention on Offences and Certain Other Acts Committed on Board Aircraff; Konvensi Hague/The Hague Convention 1970 tentang kejahatan pesawat udara (Convention for the Suppression of Unlawful Seizure of Aircraff); Konvensi Montreall Montreal Convention 1971 tentang kejahatan yang dilakukan terhadap pesawat terbang sipil (Convention for the Suppression of Unlawiul
Acts Against the Safety of Civil Aviation).

Munculnya konvensi-konvensi tersebut sebenarnya tidak lepas dari makin maraknya kejahatan yang terjadi diatas pesawat udara ataupun terhadap sarana dan prasarana penerbangan yang dapat mengancam hak hidup, kebebasan dan keamanan. Menurut Zen Kejahatan itu mempunyai implikasi luas bagi keamanan dan perdamaian global. ${ }^{49}$ Kejahatan-kejahatan yang dimuat dalam Undang Undang Nomor 4 tahun 1976 tersebut yang kemudian dimasukkan dalam Bab tambahan dalam Bab XXIXA Kitab Undang Undang Hukum Pidana (KUHP) dikemudian hari ternyata diperluas lagi bentuk kejahatannya dan dirumuskan menjadi tindak pidana terorisme. ${ }^{50}$

Ada sebanyak dua belas konvensi internasional yang mengatur tentang pencegahan dan penindasan terhadap terorisme internasional, termasuk di dalamnya adalah norma-norma yang mengatur tanggungjawab negara dalam menjawab problem terorisme. Dari dua belas konvensi internasional tersebut berdasarkan data tahun 2001, Indonesia baru menandatangani dan meratifikasi tiga buah konvensi sebagaimana yang disebut di atas, ${ }^{51}$ ditambah dengan satu konvensi tentang nuklear. Convention on the Physical Protection of Nuclear Material, Vienna, 1980. Selain itu Indonesia juga telah menandatangani dua konvensi lainnya yaitu: Protocol on the Suppression of Unlawful Act of Violence at Airports Serving Intemational Civil

\footnotetext{
${ }^{47}$ A. Patra M. Zein, "Terorisme: Standar Hukum Internasional", Tempo edisi online, 08 November 2002.

${ }^{48}$ Andy Rahmianto. op.cit.

${ }^{49}$ A. Patra M. Zein. op.cit.

${ }^{50}$ Pasal 8 huruf a $-r$, dan Penjelasan Pasal 8 Perpu Nomor 1 Tahun 2002.

${ }^{51}$ Lihat Undang-Undang Nomor 2 Tahun 1976 tentang pengesahan terhadap konvensi Tokyo, Hague, dan Montreal. Lihat juga Andy Rahmianto, Indonesia dan Terorisme Intemasional. op.cit.
} 
Aviation, Supplementary to the Convention for : the Suppression of Unlawful Acts Against the Safety of Civil Aviation, Montreal, 1988. Dan Intemational Convention for the Suppression of the Financing of Terorism tahun 1999. ${ }^{52}$

Perumusan perbuatan-perbuatan yang akan dikategorikan menjadi tindak pidana dalam proses kriminalisasi menurut Muiadi ${ }^{53}$ dapat dilakukan dalam tiga macam kemungkinan cara yaitu: pertama, beberapa konvensi internasional yang sudah ada diambil dan dirumuskan menjadi tindak pidana terorisme; kedua, menyebut, mengadopsi atau mengambil alih dari undang-undang tertentu; atau yang ketiga merumuskań perbuatan tertentu yang sebelumnya bukan tindak pidana menjadi tindak pidana terorisme. Perumusan perbuatan tertentu menjadi tindak pidana terorisme di Indonesia sebenamya tidak lepas dari salah satu cara perumusan sebagaimana yang telah dijelaskan oleh Muladi di atas dapat diuraikan sebagai berikut ini: 1. Dalam bagian Penjelasan Umum Perpu Nomor 1 tahun 2002 dijelaskan bahwa dikeluarkannya Perpu tersebut diakui sebagai komitmen pemerintah untuk mewujudkan: a. ketentuan Pasal 3 Convention Against Terroris Bombing (1977), yang dalam Perpu tersebut ketentuan yang paling mendekati dengan konvensi tersebut juga dengan Undang-Undang Nomor 12/Drttahun 1951 ada dalam Pasal 9 yang mengatur tentang larangan melakukan perbuatan melawan hukum untuk memasukkan ke Indonesia, membuat, menerima ... sesuatu senjata api, amunisi, atau sesuatu bahan peledak dan bahan-bahan lainnya yang berbahaya dengan maksud untuk melakukan tindak pidana terorisme. $b$. Convention on the Suppression of Financing Terrorism (1999). Dijelaskan juga bahwa Perpu tersebut memuat juga ketentuan tentang pendanaan untuk kegiatan tindak, pidana terorisme yang sekaligus juga dimaksudkan untuk memperkuat UndangUndang Nomor 15 tahun 2002 tentang TindakPidana Pencucian Uang. Perwujudan dari komitmen ini dapat dilihat dari ketentuan Pasal 11 sampai dengan 13 Perpu nomor 1 tahun 2002. 2. Pasal 10 Perpu No.1 tahun 2002 ini memuat ketentuan mengenai ancaman pidana terorisme bagi mereka yang mempergunakan senjata kimia, biologis, radiologi... ketentuan tersebut sebenarnya mengadopsi dari konvensi Wina 1979 "Convention on the Physical Protection of Nuclear Material. ${ }^{54} 3$. Pasal 8 Perpu Nomor 1 tahun 2002 yang mengatur tentang kejahatan penerbangan dan kejahatan terhadap saranal prasarana penerbangan menjadi tindak pidana terorisme sebenarnya merupakan penjabaran dari ketentuan Pasal XXIXA KUHP jo Undang-Undang Nomor 4 Tahun 1976 jo Undang-Undang Nomor 2 Tahun 1976 jo Undang-Undang Nomor 2 tahun 1976. ${ }^{55} 4$. Yang berisi tentang perbuatan-perbuatan yang dikategorikan sebagai tindak pidana terorisme yang merupakan perumusan delik baru yang

52 Siaran Pers dari Permanent Mission of the Republic of Indonesia to the United Nation, di New York, No.204/HMS/XII/01, tanggal 26 Desember 2001. Didownload darihttp:// www.indonesiamission-ny.org.
${ }^{53}$ Muladi, penjelasan lesan dalam kuliah di PDIH Undip, Semarang 4 Mei 2002.
${ }^{54}$ Lihat Penjelasan Pasal 9 dalam bagian Pasal Demi Pasal dalam Perpu No. 1 Tahun 2002.
${ }^{55}$ Undang-Undang Nomor 2 Tahun 1976 mengesahkan berlakunya Konvensi Tokyo 1963, Konvensi the
Hague 1970 dan Konvensi Montreal 1971. 
sebelumnya belum pernah ada antara lain dapat dijumpai'dalam Pasal $6 ; 7 ;, 47,18$, serta tindak pidana lainnya yang berkaitan dengan tindak pidana terorisme (Bab IV Pasal 20 sampai dengan 24).

\section{Simpulan}

Berdasarkan uraian diatas dapat disimpulkan beberapa hal sebagai berikut: 1. Bahwa belum ada batasan pengertian terorisme yang dapat diterima oleh berbagai pihak karena masingmasing mempunyai sudut pandang sendiri dalam memberikan pengertian terorisme. Belum adanya konsensus dari. berbagai pimpinan negara mengenai terorisme sehingga sampai saat ini masih dijumpai berbagai pengertian terorisme. 2. Meskipun belum ada batasan pengertian yang sama mengenai terorisme, namun sejak dikeluarkannya ECST tahun $1937,{ }^{56}$ pengertian terorisme yang sebelumnya dianggap sebagai kejahatan terhadap negara, pengertiannya telah bergeser kearah sebagai kejahatan terhadap kemanusiaan. Pergeseran ini semata-mata karena.tuntutan ke arah yang lebih demokratis, mengingat jika kejahatan terorisme diartikan sebagai kejahatan terhadap negara akan menimbulkan kekhawatiran adanya potensi penyalahgunaan kekuasaan untuk memberikan pengertian yang disesuaikan dengan keinginan dan kebutuhan penguasa. Perpu nomor 1 Tahun 2002 ternyata juga mengikuti arah pergeseran pengertian ini sebagaimana dapat dijumpai dalam bagian Penjelasan Umumnya: "bahwa terorisme merupakan kejahatan terhadap kemanusiaan dan peradaban...". 3 . Bahwa kejahatan terorisme tidak lagi dianggap sebagai masalah lokal, nasional ataupun regional, namun sudah dianggap oleh masyarakat intemasional sebagai suatu masalah internasional. Kejahatan terorisme sudah menjadi isu global, oleh karena itu penanganannya pun tidak cukup dilakukan oleh masyarakat lokal-nasional, namun harus melibatkan pula dengan masyarakat dari kawasan lain yang lebih luas yaitu dengan masyarakat dari kawasan regional dan intemasional. 4. Proses kriminalisasi terorisme di Indonesia tidak terlepas dari dinamika proses globalisasi yang terjadi. Sebagai bagian dari masyarakat dunia, Indonesia juga tidak akan terlepas dari situasi global yang terjadi. Karena terorisme sudah menjadi isu global yang harus ditanggulangi dan ditumpas bersama oleh seluruh anggota masyarakat dunia, maka bagi Indonesia suka ataupun tidak, dituntut untuk berpartisipasi dalam mengatasi masalah terorisme. Dalam konteks seperti inilah Perpu nomor 1 tahun 2002 tentang pemberantasan tindak pidana terorisme dikeluarkan oleh pemerintah, meskipun akselerasi atau percepatan keluamya Perpu tersebut dipicu oleh peristiwa peledakan bom di Kuta Bali. Penegasan sikap ini telah disebutkan dalam konsiderans Perpu nomor 1 tahun 2002 bagian Menimbang pada hunuf d: "Bahwa pemberantasan terorisme didasarkan pada komitmen nasional dan internasional dengan membentuk peraturan perundangundangan yang berkaitan dengan terorisme." 5 . Ada tiga macam cara yang ditempuh dalam merumuskan tindak pidana terorisme dalam Perpu Nomor 1 Tahun 2002 yaitu: pertama, dengan mengadopsi dari konvensi-konvensi

${ }^{56}$ ECST singkatan dari European Convention on The Suppression of Terrorism. 
Muh. Arif Setiawan. Kriminalisasi Terorisme di Indonesia ...

internasional; kedua, mengadopsi atau memperluas dari undang-undang lain yang sudah ada sebelumnya; ketiga, adalah merumuskan bentuk kejahatan baru yang dikategorikan sebagai tindak pidana terorisme.

\section{Daftar Pustaka}

Adji, Indriyanto Seno. "Terorisme dan Hukum", harian Kompas, 24 September 2001, edisi cetak, di down load dari http:/l uww.kompas.com.

-., "Bali, Terorisme, dan Hak Asasi Manusia", harian Kompas, 29 Oktober 2002.

Alfian $M_{i}$ M. Alfan. "Momentum Kebangkitan Islam Moderat", harian Kompas, 1 Pebruari 2002.

Arif, Barda Nawawi. Bunga Rampai Kebijakan Hukum Pidana, Bandung: PT. Citra Aditya Bakti, 1996.

Ariwibowo, Dede. "Perang Terorisme Tidak Selalu Aksi Militer", harian Tempo Interaktif, Jakarta, 11 Oktober 2001.

Bagun, Rikard. "Terorisme, Gejala Global", harian Kompas Cyber Media, 20 September 2001, didown load dari http:Ill www.kompas.com.

_-. "Indonesia di Peta Terorisme Global", harian Kompas, 17 November 2002.

Dimyati, Khudzaifah dan Kelik Wardiono, eds. Problema Globalisasi: Perspektif Sosiologi Hukum, Ekonomi dan Agama, Surakarta: Muhammadiyah
University Press, 2000.

Giddens, Anthony. "The Third Way: The renewal of Social Democracy", (terjemah) Ketut Arya Mahardika, Jalan Ketiga: Pembaharuan Demokrasi Sosial, Jakarta: Gramedia Pustaka Utama, cetakan ketiga, 1999.

_., "Runaway word: How Globalization is Reshaping Our Lives", (terjemah) Andry Kristiawan dkk. Dunia Yang Lepas Kendali: Bagaimana Globalisasi Merombak Kehidupan kita, Jakarta: Gramedia Pustaka Utama, 2001.

Habibie, Bacharuddin Jusuf. "Human Right, Human Responsibility, And Human Security", makalah dalam workshop XIX Intemational Workshop on Global Security and the War on Terrorism, Berlin - Federal Republic of Germany, 3-6 Mei 2002.

Juwono, Hikmahanto. "Catatan Singkat RUU Anti Terorisme", makalah dalam seminar sehari tentang Terorisme, DepokJakarta, Mei 2002.

Lutan, Ahwil."Terorisme", makalah dalam seminar sehari Sosiologi Hukum, di Universitas Pelita Harapan, Jakarta, 25 Maret 2002.

Mere, Steven. "Siapa Teror Siapa", makalah, Poskup, 2002.

Muladi. Refleksi dan Rekonstruksi Wajah Hukum Indonesia Menapak Tahun 2002 dan Permasalahan Penegakan Hukum, Jakarta: The Habibie Center, 7 Pebruari 2002. 
Nusantara, Abdul Hakim Garuda. "Mengkritisi RUU Pemberantasan Terorisme", makalah disampaikan dalam Seminar RUU Tentang Pemberantasan Terorisme, Jakarta 3 Desember 2001.

Paulus, Loudewijk F. Terorisme. buletin Litbang Departemen Pertahanan, nomor edisi tidak diketahui, http:/l www.buletinlitbang.dephan.go.id.

Powell, Collin. "Menangkap Momentum: Tentang Serangan Teroris 11 September", Jurnal Elektronik, "US. Foreign Policy Agenda", edisi 14 November 2001, didownload dari http:/l wuw.usembassy.state.gov

Rahmianto, Andy. "Indonesia dan Terorisme Internasional", harian Kompas, 29 Oktober 2001.

Rancangan Undang Undang Republik Indonesia tentang Pemberantasan Terorisme, didownload dari hukumonline.com

Rhiti, Hyronimus. "Kérjasama Antiterorisme", harian Kompas, edisi cetak, 13 September 2001.

Rice, Condoleezza. "Perang Ini Untuk Melawan Terorisme, Bukan Islam", Kedutaan Besar Amerika Serikat di Jakarta, Siaran Pers Kedutaan Besar Amerika Serikat, 17 Oktober 2001, http://www.usembassy.state.gov

Skopeonet the Asia's Smartest dot, Penanganan Terorisme di Kawasan Pasifik Akan Dibahas Pada SPWD, berita, 2 Oktober 2002, jam 18.33 didownload dari http:/l www.skopeonet.com/newsfokus.
Subagijo, Stevanus. PropagandaAntiterorAlaAS, Suara Karya online, 12 November 2002.

Subagyo, Agus. "Satu Tahun Tragedi WTC 11 September 2000", harian Pikiran Rakyat, 2002.

Sukma, Rizal. "Reaksi Amerika Persulit Muslim Moderat", jurnal elektronik Islamic.com (Jaringan Islam Liberal), http://wuwwislamlib.com

—, "Indonesia dan Kecenderungan Intervensi Internasional", Jumal Analisis CSIS, Tahun XXX/2001 No.1, Jakarta: Centre For Strategic and International Studies (CSIS), 2001.

Sulistyo, Hermawan ḍk Eds. Beyond, Terrorism: Dampak dan Strategi Pada Masa Depan, Jakarta: Pustaka Sinar Harapan, diterbitkan atas kerjasama Conflict and Peace Research Network (CONCERN) dan Friedrich Ebert Stiftung (FES), 2002.

Wilson, Edward 0. Consilience: The Unity of Knowledge, New York: Alfred A. Knopf, 1998.

Wirajuda, Hassan N. Paparan Lisan (Executive Summary) Permyataan Pers Akhir Tahun Menteri Luar Negeri Republik Indonesia, Departemen Luar Negeri Republik Indonesia, Jakarta, 7 Januari 2002.

Wolfowitz, Paul. "Perang Ini Bukan Hanya Perang Amerika", Kedutaan Besar Amerika Serikat di Jakarta, Siaran Pers Kedutaan Besar Amerika Serikat, 11 Oktober 2001, Artikel Opini Untuk Pers 
Muh. Arif Setiawan. Kriminalisasi Terorisme di Indonesia ...

Indonesia, http:/hww.usembassy.state.gov

_. "Meski Tercapai Keberhasilan di Afganistan, Al-Qaeda Tetap Menjadi Ancaman Dunia", Transkrip wawancara Wolfowitz di Televisi 28 November, Kedutaan Besar Amerika Serikat di Jakarta, Siaran Pers Kedutaan Besar Amerika Serikat, 2 Desember 2001, http://wuww.usembassy.state.gov

Zen, A. Patra M. "Terorisme: Standar Hukum Internasioanal", Tempo online, 8 November 2002.

Undang-Undang Republik Indonesia Nomor 4 Tahun 1976 tentang Perubahan dan Penambahan Beberapa Pasal Dalam KUHP Bertalian Dengan Perluasan Berlakunya Ketentuan Perundang: Undangan Pidana, Kejahatan Penerbangan dan Kejahatan Terhadap Sarana/Prasarana Penerbangan, Lembaran Negara Republik Indonesia Tahun 1976 Nomor 26.

Peraturan Pemerintah Pengganti UndangUndang Republik Indonesia Nomor 1 Tahun 2002 tanggal 18 Oktober 2002 tentang Pemberantasan Tindak Pidana Terorisme, Lembaran Negara Republik Indonesia, Tahun 2002, nomor 106. Beserta Penjelasannya (Lembaran Negara Republik Indonesia, Tahun 2002, nomor 4232).

Peraturan Pemerintah Pengganti UndangUndang Republik Indonesia Nomor 2 Tahun 2002 tanggal 18 Oktober 2002 tentang Pemberlakuan Peraturan. Pemerintah Pengganti UndangUndang Republik Indonesia Nomor 1
Tahun 2002 Tentang Pemberantasan Tindak Pidana Terorisme Pada Peristiwa Peledakan Bom di Bali tanggal 12 Oktober 2002. Lembaran Negara Republik Indonesia, Tahun 2002, nomor 107. Beserta penjelasannya (Lembaran Negara Republik Indonesia, Tahun 2002, nomor 4233).

Instruksi Presiden Republik Indonesia Nomor 4 Tahun 2002 tanggal 22 Oktober 2002 tentang Langkah-Langkah Pemberantasan Tindak Pidana Terorisme.

Buletin Litbang Departemen Pertahanan, volume V No.7 Juli 2001, didownload dari http://www.buletinlitbang.dephan.go.id

Harian Kompas. "Ketidakadilan Lahirkan Terorisme", 2 November 2001.

Harian Kedaulatan Rakyat. Yogyakarta, 9 November 2002.

Harian Kompas. Deklarasi Beirut dan Isu Terorisme, 31 Maret 2002.

Harian Kompas. Represi Israel Membenarkan Keragaman Pengertian Terorisme, 3 April 2002.

Harian Kompas. Isu Terorisme Jangan Memecah Belah Kita, 23 September 2002.

Harian Kompas. DPR Diminta Sempurnakan Perpu Antiterorisme, 29 Oktober 2002.

Kedutaan Besar Amerika Serikat di Jakaria, Siaran Pers Kedutaan Besar Amerika Serikat, 17 Oktober 2001, Public Affairs Section, "Departemen Keuangan' AS Mempublikasikan Daftar Tambahan Nama 39 Teroris", . http:ll 


\section{$\therefore$ www.usembassy.state.gov}

Kedutaan Besár Amerika Serikat di Jakarta, Siaran Pers Kedutaan Besar Amerika Serikat, 8 November 2001, Public Affairs Section, "Lembar Fakta: Gedung Putih Soal Penghentian Aliran Dana Untuk Teroris, Rekening 62 Organisasi dan Perorangan Diblokir", http:// www.usembassy.state.gov

Kedutaan Besar Amerika Serikat di Jakarta, Siaran Pers Kedutaan Besar Amerika Serikat, 2 Agustus 2002, "Lembar Fakta: AS dan Indonesia Memulai Program Anti Teroris Jangka Panjang, Lebih Dari $\$ 50$ Juta Dianggarkan Untuk Pelatihan
Polisi dan Militer", http:// www.usembassy.state.gov

Kompas Cyber Media. "Dunia Nyatakan Perang Lawan Terorisme", 14 September 2001.

Kompas Cyber Media. "AS Tawarkan Bantuan Pembaharuan Hukum Untuk Perangi Terorisme", 20 November 2001.

Permanent Mission of the Republic of Indonesia to the United Nation, Siaran Pers No.204/HMS/XII/01:tentang Kesediaan Indonesia melaksanakan Resolusi DK PBB No. 1373 tahun 2001, New York 26 Desember 2001. ' 